\title{
Wieliczka Salt Mine and its history written in annual growth rings of spruce wood
}

\author{
Elżbieta SZYCHOWSKA-KRAPIEC ${ }^{1, *}$ and Krzysztof DUDEK ${ }^{1}$ \\ 1 AGH University of Science and Technology, Faculty of Geology, Geophysics and Environmental Protection, \\ Al. A. Mickiewicza 30, 30-059 Kraków, Poland
}

\begin{abstract}
Szychowska-Krapiec, E., Dudek, K., 2014. Wieliczka Salt Mine and its history written in annual growth rings of spruce wood. Geological Quarterly, 58 (3): 617-622, doi: 10.7306/gq.1157

This paper presents results of dendrochronological analysis of spruce wood from the Wieliczka Salt Mine, one of the oldest mines in Poland. The wood came from the first level of the mine, from casings of drifts, chambers, mineshafts, short shafts, galleries and chapels. The oldest wood, representing spruce trees cut down in the 15th century, appears in the Wałczyn, August and Dusząca chambers, Bąkle chamber and Powroźnik gallery, as well as the cast between the Kaczorowski and Sroki chambers. Younger wood, from the 16th and 17th century, was recognized in the Krupiński, Dusząca, Reyna and Weszki chambers, the Leszno and Karol galleries, the Sułów short shaft, and the Lizak chapel. The 18th-19th century wood appears in the August, Wałczyn, Duszaca, Rex and Kloski chambers, the Klemens gallery, the Piżmowa chapel, and the Wałczyn short shaft. In two excavations of the August and Weszki chambers, fragments of 20th century wood were recognized. Wood from old mines is a valuable source of information on history of the mining excavations or tools used in the mines. It also allows extending the scope of research of the mining archaeology.
\end{abstract}

Key words: Picea abies, Wieliczka Salt Mine, mining casings, annual growths, dendrochronology, mining archaeology.

\section{INTRODUCTION}

The Salt Mine in Wieliczka, situated in the Badenian (Middle Miocene) salt-bearing formation of the Polish Carpathian Foredeep (Garlicki, 1979), is one of the oldest mines in Poland; beginnings of its mining activity reach back to the 13th century. Since that time, it has incessantly operated and the excavations formed at the salt exploitation constitute valuable historic substance. The oldest of them are situated in the first level Bono, at a depth of about $58 \mathrm{~m}$ relative to the Kinga mineshaft. Mediaeval objects, among others, drifts, shafts, chambers, galleries and underground chapels, hide in themselves the history of the aged mine. They are invaluable, even in spite of the current condition of the excavations, in places far from perfect. They are a rich source of knowledge on the development of techniques of the deposit exploitation, and they also yield the image of knowledge and abilities of generations of the miners. This historical value was confirmed by listing the Wieliczka Salt Mine in the UNESCO World Cultural and Natural Heritage List. Remains of the ancient mining are investigated by the mining archaeology. To a considerable degree, it is supported by dendrochronology, which is of key importance for reading the information written chronologically in tree rings, year after year. Therefore, wood preserved in old mines is so valuable; once in-

\section{* Corresponding author: szycha@geol.agh.edu.pl}

Received: January 15, 2014; accepted: February 27, 2014; first published online: March 21, 2014 troduced into the mining excavations allows to follow the chronology of functioning of devices, excavation casings, their reconstructions or renovations. Analysis of annual growth rings allows determining the age of trees, from which wooden elements were made, with the accuracy of a single year. Dendrochronology is helpful in reconstructing the chronology of mine excavations, it also provides useful, exact information for establishing the history of the mines. In Europe, only several selected tree species are used for dendrochronological analysis: Abies alba, Picea abies, Pinus sylvestris, Larix decidua, Quercus sp., Ulmus sp., Fagus sylvatica and Alnus sp. Over 700 years of mining activity in the Wieliczka Salt Mine resulted in vast amounts of wood gathered within that period of time. Wood was delivered to the mine from various areas; in the beginning from close to Wieliczka, then, with elapse of time, from more and more distant mountains, like the Island Beskids (Beskid Wyspowy) or Silesian Beskids (Beskid Śląski). Various provenances of wood in the mine creates high potential of exploiting this advantage in further dendrochronological research. The wood was used as material for the excavation casings, as well as for construction of transport devices, production of mining tools (blockheads, hoes), or construction of draining devices (gutters, pipes). The investigations carried out by the authors were aimed at reaching and sampling the oldest wood from the mine to determine its age. This, in turn, should help in establishing the time of formation of the excavations, their history, and the time of functioning. Wood from the mine is an excellent store of potential material to establish dendrochronological standards, for coniferous tree species in particular. 


\section{MATERIALS AND METHODS}

Wood gathered in the mine is excellent material for dendrochronological investigations. However, difficult conditions at some sites of the mine: tight or too dangerous excavations, collapse threats, tightened roofs and walls, or crumpled casings effectively make it impossible to reach the sites at which huge trunks appear. Moreover, in spite of their impressing sizes, they appear not to be suitable for analyses, because they are either strongly cracked or crushed (Fig. 1).

Therefore, sampling had to be limited to the sites. Samples were taken with a wood handsaw and a Pressler increment borer. Combustion saws and drillers could not be used because of the methane gas present in the mine.

Sampling was made in the oldest mediaeval excavations from the first level, stretching at a depth of $57.4 \mathrm{~m}$ relative to the Kinga shaft (Jodłowski, 1988). These are eleven chambers (Reyna, Krupiński, Powroźnik, Wałczyn, August, Mortis, Dusząca, Weszki, Rex, Fortynbark, between the Gębaliński gallery and the Boża Wola mineshaft), three short shafts (Wałczyn, Zigler, Sułów), three galleries (Leszno, in front of the Piżmowa chapel, Bakle), two perpendicular galleries (Karol, Powroźnik), as well as the Kloski and Stara Stajnia chambers and the Lizak chapel. The sampled wooden elements that form circular slices or cores were analysed with a stereoscopic microscope; 67 of them represent spruce. They came from casings of excavation walls or casts that appear there (Fig. 2).

Measurements of annual growth width, with $0.01 \mathrm{~mm}$ accuracy, were made using a DENDROLAB1.0 apparatus at the Dendrochronological Laboratory of the AGH University of Science and Technology in Kraków (Poland). The measurements were registered and the annual growth sequences were graphically presented using a package of TRMEAS programs (Krawczyk and Krapiec, 1995). Pearson's coefficient of the linear correlation $r$ and the value $t$ (Baillie and Pilcher, 1973) were calculated with the software of TREE-RINGS (Krawczyk and Krapiec, 1995) and COFECHA (Holmes, 1999). When identifying the best fitting positions of the individual sequences, high $r$ and $t$ values, as well as visual resemblance to the dendrochronological curves were considered.

Individual sequences were dated against spruce master chronologies constructed for:

- southern Poland (1390-2001 AD) (Szychowska-Krapiec, 2004);

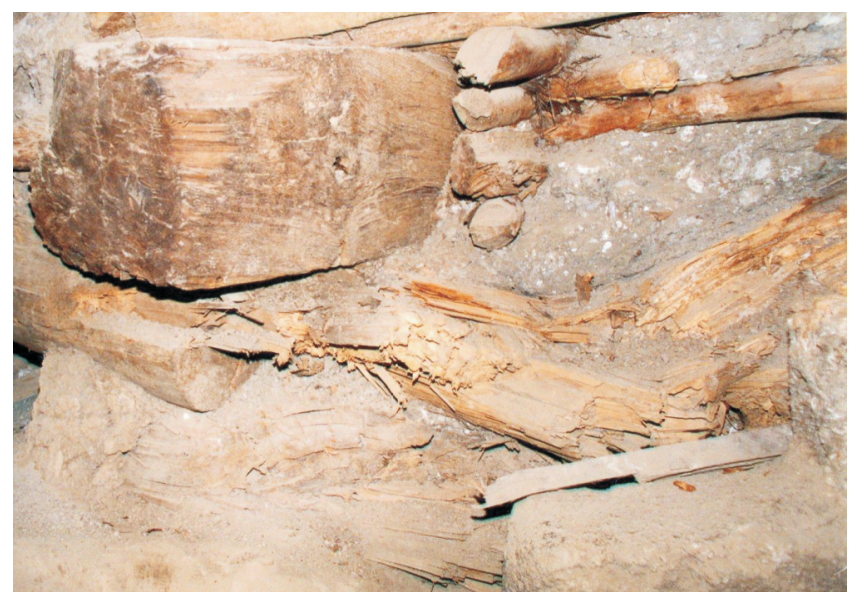

Fig. 1. Examples of huge, strongly cracked and crushed trunks (photograph by J. Przybyło)

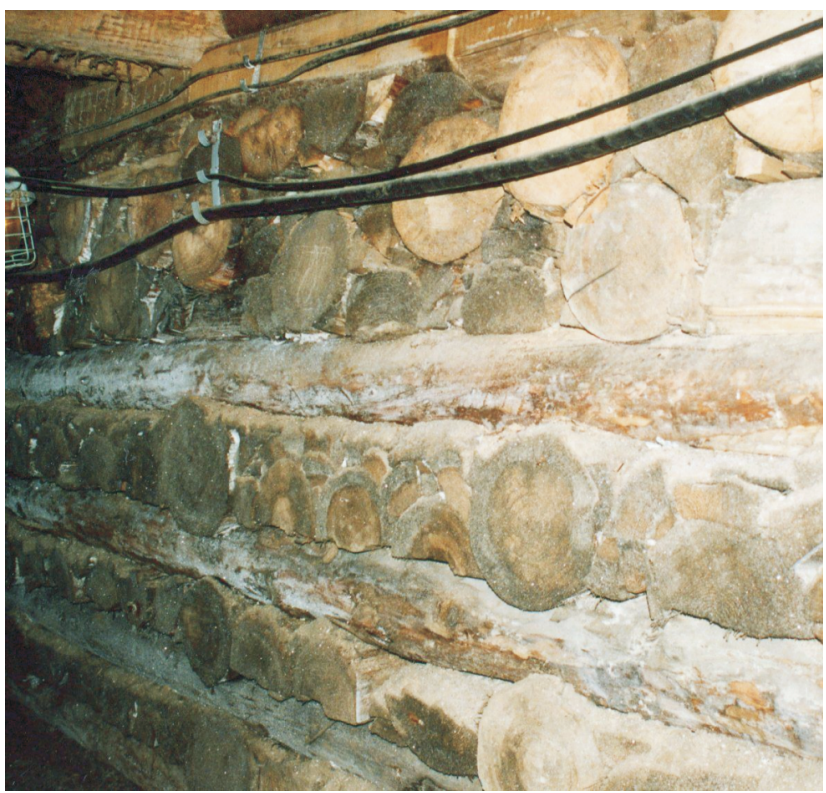

Fig. 2. A spruce wood cast, sampled for dendrochronological analysis (photograph by J. Przybyło)

- Bohemia and Moravia (1279-1997 AD) by T. Kyncl and J. Kyncl (unpubl.).

Taking into account that all the samples analysed were devoid of their last, youngest rings, developed directly under the bark, only a terminus post quem dating was possible (Zielski and Krapiec, 2004). Evaluation of the number of lacking rings is difficult, although in most cases of samples taken from round beams it is less than twenty.

\section{RESULTS}

The individual ages of spruce trees used for casings vary from 30 to 177 years, however, most of timbers $(60 \%)$ come from trees between 61 and 177 years. Generally, the tree rings were regularly developed, without disorders. Double or missing rings have not been found. At the microscopic inspection, the anatomical structure of wood was visible satisfactorily enough to carry out the measurements of width of the annual growth rings. Cell walls of the tracheids were clearly marked, without mechanical distortions: crumpling or damages. Borders between the tracheids of early and late wood were legible. Coniferous wood, susceptible to absorb salty damp, was well-preserved, without traces of decaying. Excellent condition of the spruce wood, with clear anatomical structure and distinct borders between the annual growth rings, enabled effective dating.

Absolute dating was made on 34 samples (Fig. 3 and Table 1). For every piece of wood analysed, corresponding numbers of tree rings, dating of individual sequences, and (estimated) dates of cutting the trees down are presented in Table 1, together with exact locations of the excavations, from which the timbers were sampled. The investigations were carried out in the northern, southern, eastern, western, and central part of the Bono level. Most of the timbers dated came from the northern part, in which also most of the oldest, 15th century wood was identified.

The oldest trees represented by the samples were felled in the 15th, and the youngest ones in the 20th century. The 


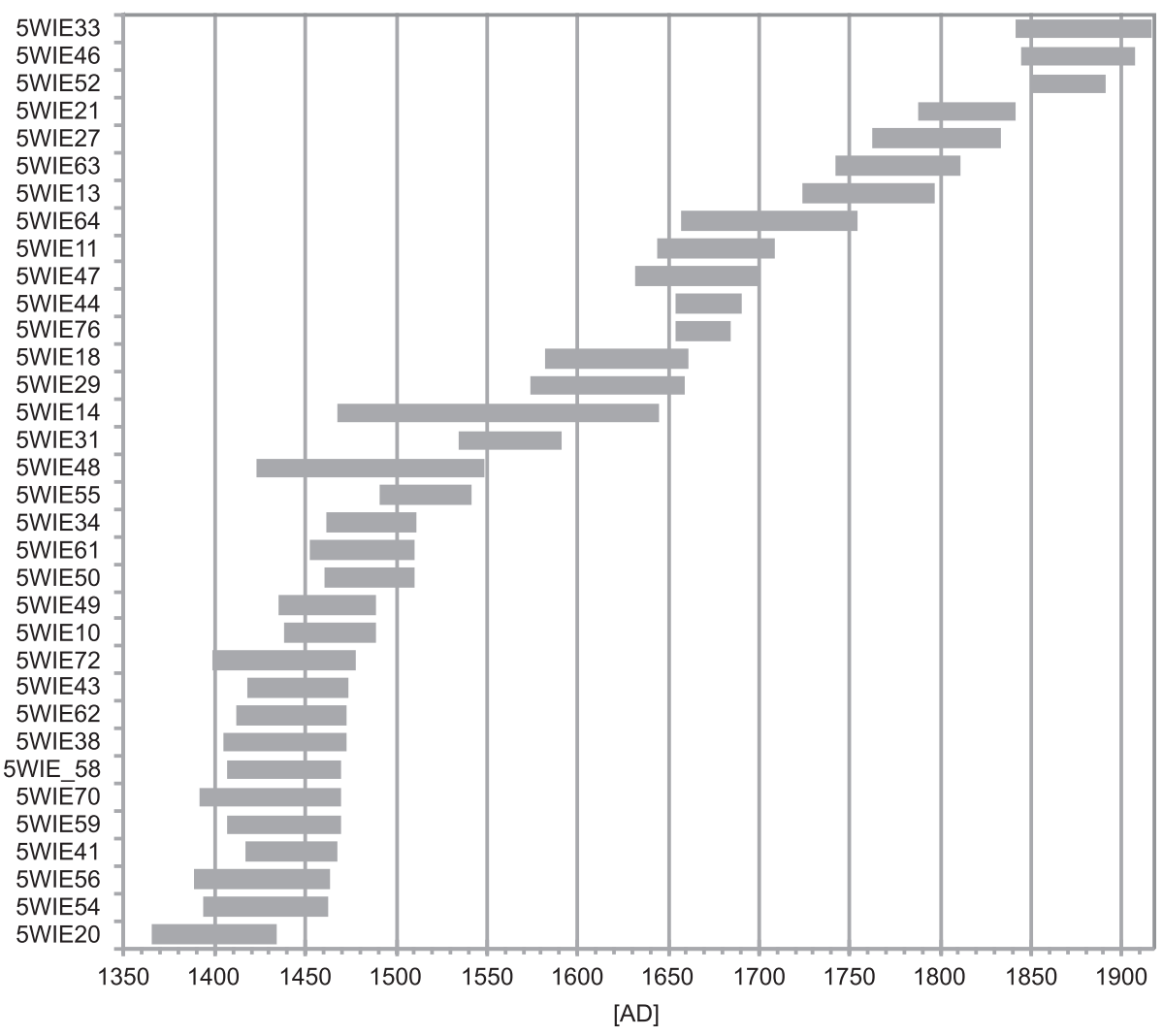

Fig. 3. Temporal extent of growth sequences of spruce trees, sampled from the Wieliczka Salt Mine

amounts of samples representing the following centuries are presented in Figure 4.

Amongst the wood, most timbers represented trees cut down in the 15th century (40.6\%), particularly in its second half, and only one timber came from a spruce cut in the first half of the century. The 15th century wood was recognized in the Wałczyn (1470 AD, 1473 AD), August (1468 AD, 1473 AD, 1474 AD) and Dusząca (1463 AD, 1464 AD, 1470 AD, 1489 AD) chambers, the Bakle (1464 AD, 1489 AD) and Powroźnik (1470 AD) galleries, and in the cast between the Kaczorowski and Sroki chambers (1478 AD) (Fig. 5).

Significantly less wood came from the 16 th $(18.7 \%)$ and 17 th $(15.6 \%)$ centuries. Six wooden elements coming from spruces cut down in the first half of the 16th century were found in the Krupiński and Dusząca (1510 AD), Weszki (1511 AD) and Duszaca (1542 AD) chambers, and in the Leszno gallery (1549 AD), whereas one timber, from the short shaft of Sułów, represented a spruce cut down later - in 1591 AD (Fig. 6).

The 17th century spruce wood was observed in the Dusząca (1645 AD, 1662 AD) and Reyna (1684 AD) chambers, the Karol gallery (1691 AD), and the Lizak chapel (1659 AD). These trees were cut down mainly in the second half of the 17th century, except one spruce which was most probably felled somewhat earlier - in 1645 AD. That tree, however, was of great age - over 177 years (Fig. 7 )

Younger, 18th and 19th century wood proved to occur in lower amounts - only $12.5 \%$ from each of these centuries. The 18th century timbers were found in the August chamber (1700 AD), Klemens gallery (1709 AD), Piżmowa chapel (1797 AD) and the short shaft of Wałczyn (1754 AD) (Fig. 8), whereas the 19th century ones - in the Wałczyn (1811 AD), Dusząca (1891 $A D), \operatorname{Rex}(1833 A D)$, and Kloski (1841 AD) chambers (Fig. 9).

Individual sequences were relatively short and contained from 41 to 97 growth rings. The youngest, 20th century wood
(August chamber - 1907 AD, and Weszki chamber - 1916 AD) came from spruces cut down in the 1920s; they were over 60 and 70 years old.

There is also the presence of deciduous, scattered-vascular wood of the Fagus sylvatica species. That beech wood has been preserved in a very good condition, with regularly developed core rays and distinct annual growths. It is characterized by several zones of narrow growths in its older part, whereas the younger rings are wider. The beech timber consists of over 100 tree rings. Unfortunately, hetero-connection with the oak regional standard for southern Poland and with the south Polish fir standard was unsuccessful.

\section{DISCUSSION}

Most of the wood pieces were identified as 15th century timbers, which are the oldest ones. Considerable amount of the 15th century wood can be related to technological changes that took place in the mine at that time. At the turn of the 14th century, more advanced devices were applied, so-called hand crosses, which considerably facilitated transport in the mineshafts and draining of the excavations. Soon, in the second half of the 15th century, other changes occurred; hand crosses were replaced by horse gears, which significantly contributed to the increase of the output (Przybyło and Sadkiewicz, 2013). Production growth required collateral security measures and, consequently, more and more increasing supplies of wood, which was used, among others, to construct mining casings and devices, and to secure the excavations.

In addition to increased supplies, there is also evidence for secondary use of older wood in the mine. An interesting example is the Weszki chamber, most probably dug out before 
Table 11499 AD (Jaworski et al., 1984),

Results of dating of spruce wood in the first-level excavations of the Wieliczka Salt Mine

\begin{tabular}{|c|c|c|c|c|}
\hline No. & $\begin{array}{l}\text { Laboratory } \\
\text { code }\end{array}$ & Location & $\begin{array}{c}\text { Tree } \\
\text { ring } \\
\text { number }\end{array}$ & $\begin{array}{l}\text { Dating of the } \\
\text { sequence }\end{array}$ \\
\hline 1 & 5WIE41 & $\begin{array}{l}\text { August chamber, E part of the deposit, } \\
\text { Piżmowa chamber area }\end{array}$ & 51 & $1418-1468$ \\
\hline 2 & 5WIE38 & $\begin{array}{l}\text { August chamber, E part of the deposit, } \\
\text { Piżmowa chamber area }\end{array}$ & 68 & $1406-1473$ \\
\hline 3 & 5WIE43 & $\begin{array}{l}\text { August chamber, E part of the deposit, } \\
\text { Piżmowa chamber area }\end{array}$ & 56 & $1419-1474$ \\
\hline 4 & 5WIE47 & $\begin{array}{l}\text { August chamber, E part of the deposit, } \\
\text { Piżmowa chamber area }\end{array}$ & 69 & $1632-1700$ \\
\hline 5 & 5WIE46 & $\begin{array}{l}\text { August chamber, E part of the deposit, } \\
\text { Piżmowa chamber area }\end{array}$ & 62 & $1846-1907$ \\
\hline 6 & 5WIE54 & $\begin{array}{l}\text { Duszaca chamber, } \mathrm{N} \text { part of the deposit, } \\
\text { Regis shaft area, Bakle complex }\end{array}$ & 69 & $1395-1463$ \\
\hline 7 & 5WIE56 & $\begin{array}{l}\text { Duszaca chamber, } \mathrm{N} \text { part of the deposit, } \\
\text { Regis shaft area, Bakle complex }\end{array}$ & 75 & $1390-1464$ \\
\hline 8 & 5WIE70 & Dusząca chamber, $\mathrm{N}$ part of the deposit & 78 & $1393-1470$ \\
\hline 9 & 5WIE49 & $\begin{array}{l}\text { Duszaca chamber, } \mathrm{N} \text { part of the deposit, } \\
\text { Regis shaft area, Bąkle complex }\end{array}$ & 54 & $1436-1489$ \\
\hline 10 & 5WIE50 & $\begin{array}{l}\text { Duszaca chamber, } \mathrm{N} \text { part of the deposit, } \\
\text { Regis shaft area, Bakle complex }\end{array}$ & 50 & $1461-1510$ \\
\hline 11 & 5WIE55 & $\begin{array}{l}\text { Duszaca chamber, } \mathrm{N} \text { part of the deposit, } \\
\text { Regis shaft area, Bakle complex }\end{array}$ & 51 & $1492-1542$ \\
\hline 12 & 5WIE14 & $\begin{array}{l}\text { Duszaca chamber, } \mathrm{N} \text { part of the deposit, } \\
\text { Regis shaft area, Bakle complex }\end{array}$ & 177 & $1469-1645$ \\
\hline 13 & 5WIE18 & $\begin{array}{l}\text { Duszaca chamber, } \mathrm{N} \text { part of the deposit, } \\
\text { Regis shaft area, Bąkle complex }\end{array}$ & 79 & $1584-1662$ \\
\hline 14 & 5WIE52 & $\begin{array}{l}\text { Duszaca chamber, } \mathrm{N} \text { part of the deposit, } \\
\text { Regis shaft area, Bąkle complex }\end{array}$ & 41 & $1851-1891$ \\
\hline 15 & 5WIE21 & $\begin{array}{l}\text { Kloski chamber, N part of the deposit, } \\
\text { Regis shaft area }\end{array}$ & 53 & $1789-1841$ \\
\hline 16 & 5WIE61 & $\begin{array}{l}\text { Krupiński chamber, casts, S part of the de- } \\
\text { posit, Powroźnik gallery area }\end{array}$ & 58 & $1453-1510$ \\
\hline 17 & 5WIE76 & $\begin{array}{c}\text { Reyna chamber, cast, E part of the deposit, } \\
\text { Piżmowa chamber area }\end{array}$ & 30 & $1655-1684$ \\
\hline 18 & 5WIE27 & $\begin{array}{l}\text { Rex chamber, central part of the deposit, } \\
\text { Powroźnik gallery area }\end{array}$ & 71 & $1763-1833$ \\
\hline 19 & 5WIE_58 & Wałczyn chamber, W part of the deposit & 63 & $1408-1470$ \\
\hline 20 & 5WIE62 & Wałczyn chamber, W part of the deposit & 61 & $1413-1473$ \\
\hline 21 & 5WIE63 & Wałczyn chamber, W part of the deposit & 69 & $1743-1811$ \\
\hline 22 & 5WIE34 & $\begin{array}{l}\text { Weszki chamber, E part of the deposit, } \\
\text { Piżmowa chamber area }\end{array}$ & 50 & $1462-1511$ \\
\hline 23 & 5WIE33 & $\begin{array}{l}\text { Weszki chamber, E part of the deposit, } \\
\text { Piżmowa chamber area }\end{array}$ & 75 & $1842-1916$ \\
\hline 24 & 5WIE72 & cast between Kaczorowski and Sroki chambers & 79 & $1400-1478$ \\
\hline 25 & 5WIE29 & $\begin{array}{c}\text { Lizak chapel, N part of the deposit, } \\
\text { Lizak-Sułów complex }\end{array}$ & 85 & $1575-1659$ \\
\hline 26 & 5WIE20 & $\begin{array}{l}\text { Bakle chamber, N part of the deposit, } \\
\text { Regis shaft area, Bąkle complex }\end{array}$ & 69 & $1366-1434$ \\
\hline 27 & 5WIE10 & $\begin{array}{l}\text { Bakle gallery, } \mathrm{N} \text { part of the deposit, } \\
\text { Regis shaft area, Bakkle complex }\end{array}$ & 51 & $1439-1489$ \\
\hline 28 & 5WIE44 & $\begin{array}{c}\text { Karol gallery, } N \text { part of the deposit, } \\
\text { Regis shaft area }\end{array}$ & 37 & $1655-1691$ \\
\hline 29 & 5WIE11 & $\begin{array}{l}\text { Klemens chamber area, } \mathrm{N} \text { part of the deposit, } \\
\text { Regis shaft area, Museum complex, } \\
\text { ca. } 20 \mathrm{~m} \mathrm{~W} \text { from Karol gallery }\end{array}$ & 65 & $1645-1709$ \\
\hline 30 & 5WIE48 & $\begin{array}{l}\text { Leszno chamber, } W \text { part of the deposit, } \\
\text { area of crossroad with Blum gallery }\end{array}$ & 126 & $1424-1549$ \\
\hline 31 & 5WIE13 & $\begin{array}{c}\text { gallery in front of Piżmowa chapel, } \\
\text { E part of the deposit, Piżmowa chamber area }\end{array}$ & 73 & $1725-1797$ \\
\hline 32 & 5WIE59 & $\begin{array}{c}\text { Powroźnik chamber, } \\
\text { central and S part of the deposit }\end{array}$ & 63 & $1408-1470$ \\
\hline 33 & 5WIE31 & Sułów chamber & 57 & $1535-1591$ \\
\hline 34 & 5WIE64 & $\begin{array}{l}\text { Wałczyn chamber shaft, central and S part } \\
\text { of the deposit, Powroźnik gallery area }\end{array}$ & 97 & $1658-1754$ \\
\hline
\end{tabular}

whereas the wood analysed represented spruces cut down in 1511 AD. This could be due to repair of already existing casings. Such a situation took place in the Wałczyn chamber. This chamber, according to the source data (Jaworski et al., 1984), was formed at the beginning of the 18th century, however spruce pieces came from trees cut down in the 1470s (1470, 1473 AD).

The greatest amounts of the spruce wood were identified in the Duszaca chamber (Szychowska-Krapiec, 2003a) situated in the northern part of the mine, where the oldest excavations were encountered (Jodłowski et al., 1988). In wall casings of the Duszaca chamber, apart from spruce, fir wood is also abundant, which came from fir trees cut down in the 14th, 15th, 16th, 17th, and 19th centuries (Szychowska-Krapiec, 2000). Amongst the excavations, the Dusząca chamber merits particular attention. It belongs to the complex of Bakle excavations situated in the oldest part of the mine.

Apart from the Dusząca chamber, the wood of coniferous species, Picea abies, Abies alba and Pinus sylvestris, appears in the mine in other excavations of the oldest level Bono (Szychowska-Krapiec, 2003a). Samples from subsequent centuries are less frequent, however, their presence indicates that wood was being delivered to the mine in a continuous way, which, in turn, points to a considerable using up of this material. It may be supposed that wood supplies were particularly high in periods of increased salt production and development of the mine. Beside coniferous wood, which was most often used in mining casings in Wieliczka, particularly in casts, deciduous wood (Fagus sylvatica, Quercus sp.) was encountered as well. It was a good material for making various mine devices. In the Bochnia Salt Mine, the situation looks somewhat different; in mining casings, in addition to coniferous wood, wood of deciduous species, especially alder and birch, is relatively frequent (Szychowska-Krapiec, 2003b).

Chronological record of the history of mines written in tree rings may be observed not only in salt mines, but also in mines of polymetallic ores (Szychowska-Krapiec, 2007), as well as gold mines (Szychowska-Krapiec, 2005) of Lower Silesia. Unfortunately, wood appears in these mines in considerably smaller amounts, and its state of preservation is not so good as in the salt mines. 


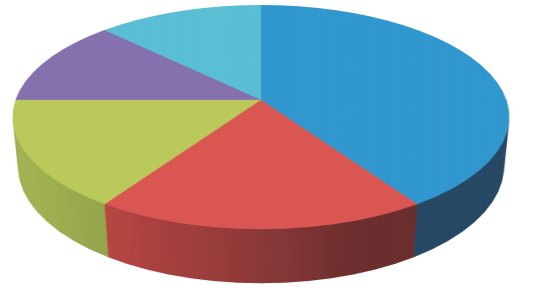

$$
\begin{array}{ll}
\mathrm{XV}-40.6 \% & \mathrm{XVII}-15.6 \% \\
\mathrm{XVI}-18.7 \% & \mathrm{XVIII}-12.5 \\
& \mathrm{XIX}-12.5 \%
\end{array}
$$

Fig. 4. Percentage of samples from particular centuries

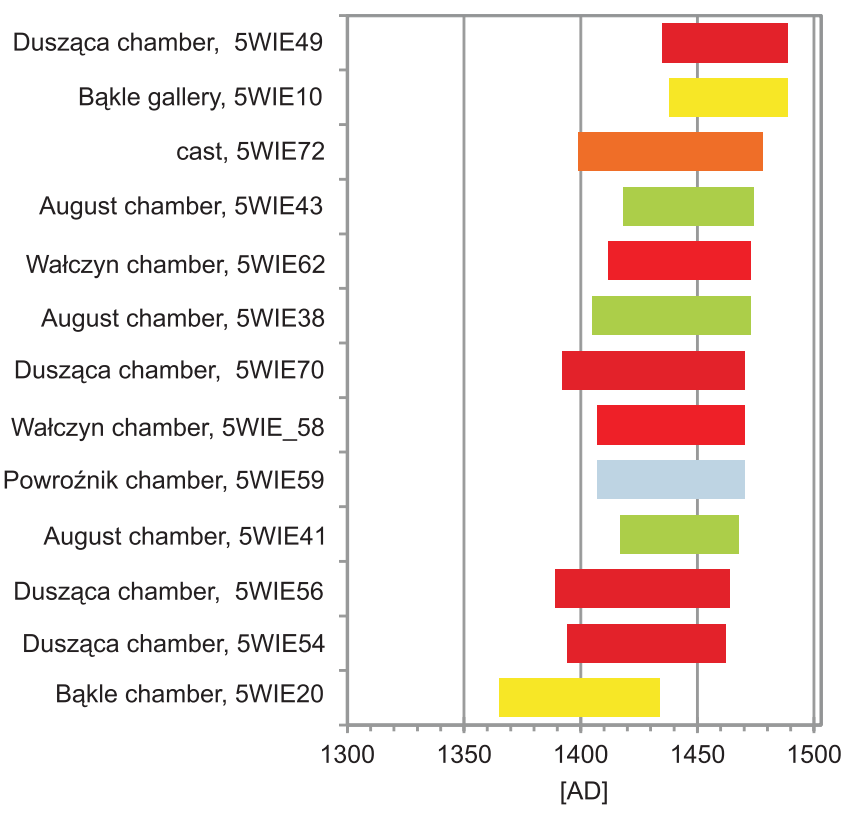

Fig. 5. Temporal extent of 15th century wood samples from various excavations in the Wieliczka Salt Mine

Significantly wider chronological record in annual growths of trees was registered in the Hallstatt salt mines (Grabner et al., 2007) and in the Kelchalm copper mine near Kitzbühel (Pichler et al., 2009) in Austria. In both Austrian mines, wooden artefacts originate from the Bronze Age all the way to the historic times, and they present remains of ancient mining works. In studies of such artefacts, dendrochronological analysis has proved to be very useful. In combination with the radiocarbon method, spruce wood from the copper mine in Tyrol was dated to 1237 BC (Pichler et al., 2009), and from the Hallstatt salt mine - to 1245 BC (Grabner et al., 2007). In both cases, it provided valuable information on the history and mining activity in Austria in the Bronze Age.

Systematic investigations of wood are valuable sources of knowledge, they also allow broadening the scope of research in mining archaeology, rapidly developing since the 1960s, e.g., in the Czech Republic (Kundrač, 1977; Kundrač and Michalek,

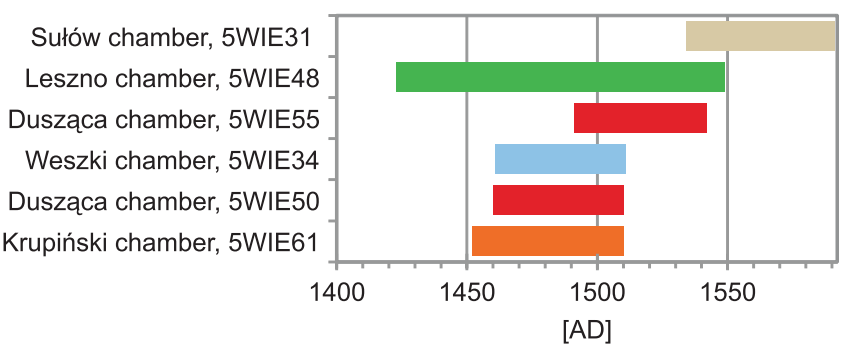

Fig. 6. Temporal extent of 16 th century growth sequences, sampled from excavations in the Wieliczka Salt Mine

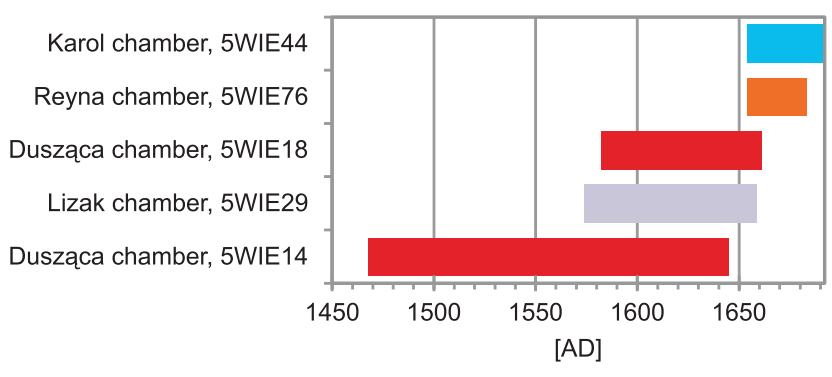

Fig. 7. Temporal extent of 17 th century wood samples from excavations in the Wieliczka Salt Mine

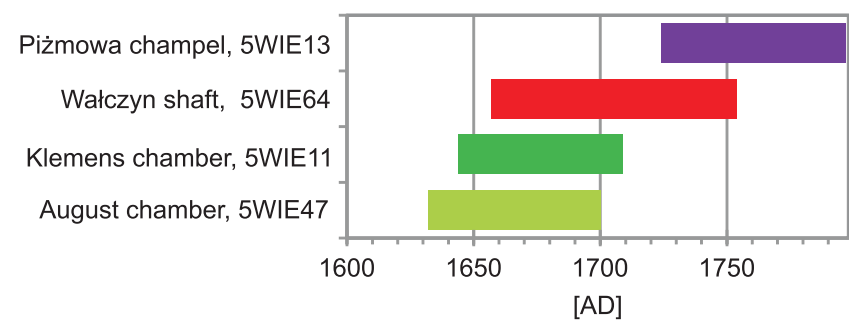

Fig. 8. Temporal extent of 18th century growth sequences, sampled from excavations in the Wieliczka Salt Mine

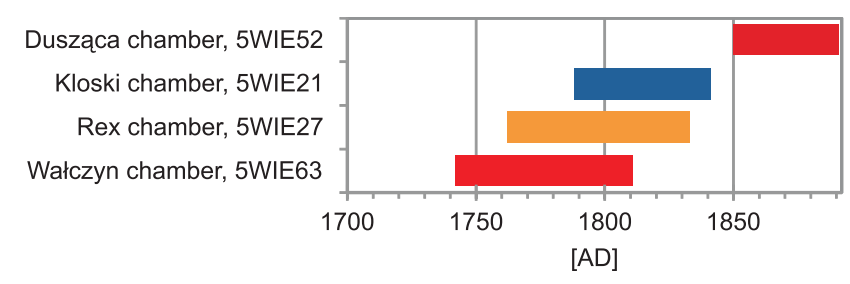

Fig. 9. Temporal extent of 19th century wood samples from excavations in the Wieliczka Salt Mine

1993) and in Poland (Madziarz and Sztuk, 2005; Firszt, 2006; Stolarczyk, 2006). Dendrochronological studies allow for more precise dating, as in the case of the Silberloch adit (Stysz et al., 2012), or revision of hypotheses on chronology of mining excavations (Szychowska-Krapiec, 2007).

Finally, the record of climatic conditions contained in annual growth rings is a good material for climate reconstruction, in particular the temperature, rainfall, and solar exposure (Szychowska-Krapiec, 2010; Koprowski and Duncker, 2012). 


\section{CONCLUSIONS}

1. Both Polish and Austrian mines discussed demonstrate high potential of the dendrochronological analysis of wood appearing in historic and prehistoric mines. The Wieliczka Salt Mine, with its 700-years history, presents an extraordinarily rich store of spruce wood. Dendrochronological analysis of 67 spruce samples allowed for absolute dating of 34 elements. The spruce timbers dated represent a broad time interval from $1434 \mathrm{AD}$ to $1916 \mathrm{AD}$.

2. Apart from the historic record, wood from mines presents excellent material for construction of regional dendrochronological standards.

3. The investigations carried out yielded the information supplementing hitherto chronological determinations. They allowed to determine the time of cutting down spruce trees used for construction of the excavation casings. They also allowed to point out times of introduction of new wooden elements into the existing casings, at the repairs or partial exchange of fragments used up.

4. Examples of secondary using of wood in the mine were recognized. Relatively late mining excavations proved to contain wood coming from spruces cut down considerably earlier. This, in turn, proves re-using of wood and economic management of the Cracow Salt Works with this expensive raw material.

Acknowledgments. The research was financed by the Faculty of Geology, Geophysics and Environmental Protection, AGH University of Science and Technology, in the framework of the statutory research No. 11.11.140.173. The authors are grateful to T. Kyncl and J. Kyncl for access to their unpublished spruce master chronology for Bohemia and Moravia, and to R. Purkiene, Z. Alexandrowicz, and an anonymous reviewer for their critical remarks.

\section{REFERENCES}

Baillie, M.G.L., Pilcher, J.R., 1973. A simple cross dating program for tree-ring research. Tree-Ring Bulletin, 33: 7-14.

Firszt, S., 2006. The archeological research of Lower Silesian ore mining (1975-2000) (in Polish with English summary). Prace Naukowe Instytutu Górnictwa Politechniki Wrocławskiej. Studia i Materiały, 117: 75-79.

Garlicki, A., 1979. Sedimentation of Miocene salts in Poland (in Polish with English summary). Prace Geologiczne, 119: 1-66.

Grabner, M., Klein, A., Geihofer, D., Reschreiter, H., Barth, F.E., Sormaz, T., Wimmer, R., 2007. Bronze age dating of timber from the salt-mine at Hallstatt, Austria. Dendrochronologia, 24: 61-68.

Holmes, R.L., 1999. Users Manual for Program COFECHA. University of Arizona, Tucson: 1-51.

Jodłowski, A., Kurowski, P., Kurowski, R., 1984. Charakterystyka zabytkowych wyrobisk kopalni soli w Wieliczce (in Polish). In: Studia i materiały do dziejów żup solnych w Polsce, 13. Wyd. MŻK, Wieliczka.

Jodłowski, A., Wiewiórka, J., Piotrowicz, J., Keckowa, A., Dziwik, K., Wyrozumski, J., 1988. Dzieje Żup Krakowskich (in Polish). Muzeum Żup Krakowskich, Wieliczka: 7-446.

Koprowski, M., Duncker, P., 2012. Tree ring width and wood density as the indicators of climatic factors and insect outbreaks affecting spruce growth. Ecological Indicators, 23: 332-337.

Krawczyk, A., Krapiec, M., 1995. Dendrochronologiczna baza danych (in Polish). Materiały Konferencyjne, II Krajowa Konferencja: Komputerowe wspomaganie badań naukowych, 14-16 grudzień, Wrocław: 247-252.

Kundráč, J., 1977. Prähistorische und mittelalterliche Goldgewinnung in Böhmen. Der Anschnitt, 29: 2-15.

Kundráč, J., Michalek, J., 1993. Urgeschichtliche und mittelalterliche Goldgewinnung in Südböhmen. In: Montanarchäologie in Europa. Berichte zum internationalen Kolloquium "Frühe Erzgewinnung und Verhüttung in Europa" in Freiburg in Breisgau vom 4. bis 7 (ed. Z. Steuer): 401-408. Oktober 1990, Sigmeringen, 1993.

Madziarz, D., Sztuk, H., 2005. Relikty dawnych robót górniczych na Dolnym Śląsku - źródło wiedzy i zagrożenie (in Polish). Bezpieczeństwo Pracy i Ochrona Środowiska w Górnictwie, 1: 22-27.

Pichler, T., Nicolussi, K., Goldenberg, G., 2009. Dendrochronological analysis and dating of wooden artefacts from the prehistoric copper mine Kelchalm/Kitzbühel (Austria). Dendrochronologia, 27: 87-94.

Przybyło, J., Sadkiewicz, J., 2013. Kalendarium ważniejszych wydarzeń związanych z Kopalnia Soli „Wieliczka” (in Polish). In: Skarb Kopalnia Soli „Wieliczka” (ed. A. Nowakowski): 191-205. Universitas, Kraków.

Stysz, M., Szychowska-Krapiec, E., Maczka, M., 2012. The Silberlochadit in the Sowie Mountains according to new archival cataloguing and dendrochronological research (in Polish with English summary). In: Dzieje górnictwa - element europejskiego dziedzictwa kultury (eds. P.P. Zagożdżon and M. Madziarz). Oficyna Wyd. Politechniki Wrocławskiej, 4: 351-377.

Stolarczyk, T., 2006. Pozostałości średniowiecznego górnictwa jako przedmiot badań archeologicznych na terenie Europy Środkowej (in Polish). Prace Naukowe Instytutu Górnictwa Politechniki Wrocławskiej, 117: 267-276.

Szychowska-Krapiec, E., 2000. The Late Holocene master chronology of fir Abies alba Mill. from southern Poland (in Polish with English summary). Geologia, 26: 173-299.

Szychowska-Krapiec, E., 2003a. Application of dendrochronological analysis in dating of timbers from the Wieliczka Salt Mine. Bulletin of the Polish Academy of Sciences, Earth Science, 51: 99-118.

Szychowska-Krapiec, E., 2003b. Przykład wykorzystania analizy dendrochronologicznej w datowaniu obudów górniczych w Kopalni Soli w Bochni. Sylwan, 147: 47-52.

Szychowska-Krapiec, E., 2004. Świerkowy standard dendrochronologiczny z obszaru południowej Polski (in Polish). Sprawozdania z Posiedzeń Komisji Naukowej PAU Oddział w Krakowie, 2: 85-88.

Szychowska-Krapiec, E., 2005. Datowanie dendrochronologiczne drewna z obudów górniczych w kopalni złota w Złotym Stoku (in Polish). Sylwan, 149: 53-59.

Szychowska-Krapiec, E., 2007. Dendrochronological studies of wood from mediaeval mines of polymetallic ores in Lower Silesia (SW Poland). Geochronometria, 26: 61-68.

Szychowska-Krapiec, E., 2010. Long-term chronologies of pine (Pinus sylvestris L.) and fir (Abies alba Mill.) from the Małopolska region and their palaeoclimatic interpretation. Folia Quaternaria, 79: 1-120.

Zielski, A., Krapiec, M., 2004. Dendrochronologia (in Polish). PWN, Warszawa. 